\title{
A AFASTABILIDADE DE OCUPANTES DE CARGOS PÚBLICOS SEM CONDENAÇÃO TRANSITADA EM JULGADO: ANÁLISE DA POSSIBILIDADE EM FACE DA MORALIDADE ADMINISTRATIVA E MITIGAÇÃO DA PRESUNÇÃO DE INOCÊNCIA OU VIOLAÇÃO CONSTITUCIONAL
}

\author{
Joaner Campello de Oliveira Junior ${ }^{1}$
}

\section{RESUMO}

Atualmente, se observa inúmeras inquirições, denúncias e até mesmo condenações pela suposta prática de crimes envolvendo ocupantes de cargos públicos. Todavia, diante da morosidade dos processos e do direito constitucional da presunção de não culpabilidade do art. 5º inciso LVII, da CF/1988, muitos mantem a ocupação do cargo público até que sejam afastados de suas funções com a condenação transitada em julgado. Neste contexto, se busca analisar a possibilidade de afastamento cautelar do agente público sem sentença transitada em julgado por meio da ponderação entre a moralidade administrativa, mitigação da presunção de inocência e a jurisprudência do Supremo Tribunal Federal.

Palavras-Chave: Constituição. Interesse público. Presunção de Inocência. Moralidade Administrativa

\section{THE DISMISSAL OF OCCUPANTS OF PUBLIC POSITIONS WITHOUT FINAL JUDGMENT: ANALYSIS OF THE POSSIBILITY IN FACE OF ADMINISTRATIVE MORALITY AND MITIGATION OF THE PRESUMPTION OF INNOCENCE OR CONSTITUCIONAL VIOLATION}

\begin{abstract}
Nowadays, there are innumerable inquiries, denunciations and convictions involving occupiers of public administration. However, in view of the slowness of the legal proceedings and the constitutional right of the presumption of non-culpability of art. 5, item LVII, of the CF / 1988, many of them maintain the occupation in the public administration until they are removed from their functions with the final judgment. In this context, the objective is to analyze the possibility of a prudent dismissal of the public agent without a final judgment by weighing administrative morality, mitigating the presumption of innocence and analyze the jurisprudence of the Federal Supreme Court.
\end{abstract}

Keywords: Constitution. Public interest. Presumption of Innocence. Administrative Morality

\footnotetext{
${ }^{1}$ Advogado. Pós-Graduado em Direito Público e Tributário pela AVM Educacional. Mestre em Direito das Relações Internacionais e MERCOSUL pela Universidad de la Empresa - Uruguai.

E-mail: joanercampello@ hotmail.com
} 


\section{INTRODUÇÃO}

No Brasil, a presunção de não culpabilidade está positivada no art. $5^{\circ}$, inciso LVII, da Constituição de 1988 ao prescrever que "ninguém será considerado culpado até transito em julgado de sentença penal condenatória". Durante muito tempo a presunção de inocência sempre foi interpretada e aplicada de forma absoluta.

Entretanto, atualmente, após os desdobramentos da Operação Lava-Jato e de tantas outras investigações se observa o assombroso número de ocupantes de cargos públicos investigados, denunciados e até condenados em crimes de diversas espécies. Apenas a titulo exemplificativo, segundo a Empresa Brasileira de Comunicação, aproximadamente 58,09\% dos parlamentares que compõem a Câmara dos Deputados e votaram no processo de impeachment já foram condenados ou respondem a processos na Justiça (inclusive eleitoral) ou Tribunais de Contas. Neste cenário, se torna forçosa uma criteriosa análise sobre o princípio da presunção de inocência, uma vez que, em sua ampla maioria os ocupantes de cargos públicos arvoram as suas defesas pela força constitucional total e absoluta de se respeitar à presunção de inocência com o escopo de garantir a permanência no cargo público até o transito em julgado da sentença condenatória. Este quadro aliado ao lento desdobramento processual mantem presumidamente inocentes ocupantes de funções públicas, enquanto ocorre o desdobramento processual. Neste contexto, se busca analisar a possibilidade de mitigação da presunção de inocência com o objetivo de preservar a coisa e o patrimônio público, por meio de interpretação constitucional, ponderando a mitigação da presunção de inocência de forma acautelatória em face da moralidade administrativa.

Inclusive, acerca da presunção de inocência o Supremo Tribunal Federal, guardião da constituição, a partir da apreciação Habeas Corpus no 126.292 muda a interpretação acerca da extensão da presunção de inocência. Até este caso, em específico, se mantinha o entendimento que para o cumprimento de pena deveria a condenação transitar em julgado. No entanto, a partir deste julgamento a Suprema Corte estabeleceu por maioria de votos a possibilidade de início da execução da pena condenatória após a confirmação da sentença em segundo grau, afirmando que esta interpretação não ofende o princípio constitucional da presunção da inocência, 
Deste modo, se observa a relevância e a atualidade deste trabalho, uma vez que, se propõe analisar se é possível ou em que medida se pode mitigar a aplicação da presunção de inocência, nos casos em que envolva a prática de crimes que causem prejuízo ao patrimônio e a coisa pública, em favor da probidade e moralidade administrativa, constituindo verdadeira medida acautelatória em que estejam de forma clara o fumus boni iuris e o periculum in mora, evitando não somente a continuidade delitiva, como o próprio prejuízo ao ente estatal e a sociedade, ou se uma interpretação constitucional neste sentido representar-se-á flagrante violação a ordem constitucional.

Para o desenvolvimento deste trabalho será utilizada a metodologia dedutiva, enquanto as principais fontes de utilizadas foram obtidas na página web do Palácio do Planalto, da jurisprudência do Supremo Tribunal Federal, e na literatura especializada em matéria de direito administrativo e constitucional.

\section{A PRESUNÇÃo DE NÃo CULPABILIDADE}

A Constituição de 1988 estabelece no art. 5, inciso LVII, que: "Ninguém será considerado culpado até o trânsito em julgado da sentença penal condenatória”. Desta forma, consagra no direito positivo constitucional brasileiro o princípio da presunção de não culpabilidade ou o principio de presunção de inocência, em outras palavras significaria dizer que ninguém poderá ser considerado culpado antes de decisão final contra a qual não caiba mais recurso, respeitados o devido processo legal, a garantia da ampla defesa e do contraditório.

Embora a Constituição de 1988 traga expressamente a presunção de não culpabilidade dentro do capítulo dos direitos e garantias fundamentais, se observa de acordo com Mendes, Coelho \& Blanco (2010, p.734-736) que a discussão sobre este princípio no direito brasileiro antecede o advento da Constituição de 1988. Os autores destacam que se indagou perante o Tribunal Superior Eleitoral e no próprio Supremo Tribunal Federal sobre o significado da presunção de inocência a partir da disposição contida no art. 153 , § 36, da Constituição de $1969^{2}$.

\footnotetext{
2 O $§ 36$ do art. 153 da Constituição de 1969 diz: A especificação dos direitos e garantias expressos nesta Constituição não exclui outros direitos e garantias decorrentes do regime e dos princípios que ela adota.
} 
Assim, em 17 de novembro de 1976, o Supremo Tribunal Federal, no Recurso Extraordinário $\mathrm{n}^{\circ}$ 86.297/SP, relatado pelo Min. Thompson Flores afirma na ementa que: “A inelegibilidade prevista no art. $1^{\circ}$, inciso I, alínea n da Lei Complementar $n^{\circ} 05$ de $1970^{3}$ é válido, por não ser inconstitucional, ainda que em parte, aquele preceito. Exegese dos art. 151, II, IV e 149, § $2^{\circ}$ da Constituição. II - Recurso Extraordinário provido. Votos Vencidos”.

Novamente, o Supremo Tribunal Federal foi instado a se manifestar sobre a extensão do principio da presunção de inocência na análise da Arguição de Descumprimento de Preceito Fundamental $\mathrm{n}^{\circ}$ 144/DF${ }^{4}$ e entendeu que a inelegibilidade somente se justificaria quando fundada em condenação definitiva em processo judicial, afirmando ainda a alta importância cívica da vida pregressa dos candidatos e o respeito à moralidade administrativa que deve ser preservada.

Extrapolando a ordem jurídica pátria, a presunção de inocência está inserida no art. $9^{\circ}$ da Declaração dos Direitos dos Homens e dos Cidadãos, de 1789, prescrevendo que: "Todo acusado é considerado inocente até ser declarado culpado e, se julgar indispensável prendê-lo, todo o rigor desnecessário à guarda da sua pessoa deverá ser severamente reprimido pela lei”. Todavia, de forma contemporânea, o Princípio da Presunção de Inocência ganhou repercussão universal na Declaração dos Direitos Humanos, da ONU, em 1948, afirmando em seu art. 11 que: "Toda pessoa acusada de delito tem direito a que se presuma sua inocência, enquanto não se prova sua culpabilidade, de acordo com a lei e em processo público no qual se assegurem todas as garantias necessárias para sua defesa".

O Brasil, ao votar na Assembleia-Geral da ONU acabou ratificando o referido princípio e a Constituição de 1988 incorporou expressamente a presunção de inocência como garantia fundamental. Todavia, a incorporação expressa desta garantia na Constituição de

\footnotetext{
${ }^{3}$ A Redação do art. $1^{\circ}$, I, n da Lei Complementar $n^{\circ} 05$ de 1970 diz que são inelegíveis os que tenham sido condenados ou respondam a processo judicial, instaurado por denúncia do Ministério Público recebida pela autoridade judiciária competente, por crime contra a segurança nacional e a ordem política e social, a economia popular, a fé pública e a administração pública, o patrimônio ou pelo direito previsto no art. 22 desta Lei Complementar, enquanto não absolvidos ou penalmente reabilitados. (grifos nossos)

4 “(...) Caráter autocrático da clausula de inelegibilidade fundada na Lei Complementar nº 5 de 1970 (art. $1^{\circ}$, I, n), que tornava inelegível qualquer réu contra quem fosse recebida denuncia por suposta prática de determinados ilícitos penais. Derrogação dessa cláusula pelo próprio regime militar (Lei Complementar ${ }^{\circ} 42 / 82$ ), que passou a exigir para fins de inelegibilidade do candidato, a existência contra ele de condenação penal por determinados delitos - entendimento do Supremo Tribunal Federal sobre o alcance da Lei Complementar $n^{\circ}$ 42/82. Necessidade que se achasse configurado o trânsito em julgado da condenação (RE 99.069/BA, Rel. Min Oscar Correa). Presunção Constitucional de Inocência: um direito fundamental que assiste a qualquer pessoa (...) Nova interpretação que reforça a exigência ético-jurídica de probidade administrativa e de moralidade para o exercício de mandato eletivo. Arguição de Descumprimento de Preceito Fundamental julgada improcedente, em decisão revestida de efeito vinculante".
} 
1988 não é o único documento de valor jurídico que absorve e reconhece a presunção de inocência como garantia fundamental. A explicação para isso é clara, uma vez que, o DecretoLegislativo ${ }^{\circ} 27$ de 1992 aprovou o texto da Convenção Americana sobre Direitos Humanos (Pacto São José) celebrado em São José da Costa Rica, em 22 de novembro de 1969. Este pacto estabelece no seu art. $8^{\circ}$, inciso I, que: "Toda pessoa acusada de delito tem direito a que se presuma sua inocência enquanto não se comprove legalmente sua culpa".

Diante disto, em matéria de presunção de inocência no Brasil tanto o art. $5^{\circ}$, inciso LVII, da Constituição de 1988, quanto à recepção e incorporação do Pacto de San José da Costa Rica a ordem jurídica pátria estabelecem e reconhecem este princípio basilar e fundamental do cidadão.

Ademais, se observa que o Supremo Tribunal Federal foi instado diversas vezes a se manifestar acerca da extensão da presunção de inocência, reconhecendo-a como um direito fundamental do cidadão que somente poderia ser considerado culpado após o transito em julgado da decisão condenatória. Neste caso, é necessário ressaltar que por meio da ADPF 144/DF se dá a orientação que devem ser considerados a vida cívica pregressa do candidato pautada na probidade e o respeito à moralidade administrativa. Entretanto, esta questão retornará a discussão quando da análise, em tópico próprio, das recentes decisões proferidas pelo Supremo Tribunal Federal.

\section{PRINCÍPIOS FUNDAMENTAIS DA ADMINISTRAÇÃO PÚBLICA: MORALIDADE ADMINISTRATIVA}

O texto da Constituição de 1988 traz em seu bojo explicita ou implicitamente os princípios fundamentais de toda a administração pública. Neste aspecto, o caput do art. 37 da Constituição Federal traz de forma explicita os seguintes princípios: legalidade, impessoalidade, moralidade, publicidade e eficiência.

De outro prisma, em sede infraconstitucional, a Lei $n^{\circ} 9.784 / 99$ que trata dos processos administrativos no âmbito federal consagra no seu art. $2^{\circ}$ os seguintes princípios: legalidade, finalidade, motivação, razoabilidade, proporcionalidade, moralidade, ampla defesa, contraditório, segurança jurídica, interesse público e eficiência.

Sem o objetivo de esgotar o tema sobre os princípios fundamentais da administração pública, faz-se necessário introduzir algumas palavras acerca de alguns princípios relevantes para o trabalho proposto, em especial, a moralidade administrativa. 
O principio da moralidade administrativa, de acordo com Alexandrino \& Paulo (2011, p. 191-194), torna jurídica a ação ética dos agentes da Administração Pública. A moralidade administrativa difere da moral comum por ser jurídica e por permitir a invalidação dos atos administrativos praticados em desacordo com este principio. Além disso, a moralidade administrativa de acordo com o paragrafo único do art. $2^{\circ}$ da Lei 9.784/99 prendese a ideia de probidade e boa-fé, uma vez que, a dicção do retro citado artigo diz que: "nos processos administrativos serão observados, entre outros, os critérios de atuação segundo padrões éticos de probidade, decoro e boa-fé".

Ao tratar do princípio da moralidade administrativa, Di Pietro (2006, p.96) escreve que:

(...) quando o conteúdo de determinado ato contrariar o senso comum de honestidade, retidão, equilíbrio, justiça, respeito à dignidade do ser humano, à boa-fé, ao trabalho, à ética das instituições. A moralidade exige proporcionalidade entre os meios e os fins a atingir; entre os sacrifícios impostos à coletividade e os benefícios por ela auferidos;

Por isso mesmo, a imoralidade salta aos olhos, quando a Administração Pública é pródiga em despesas legais, porém inúteis, como propaganda ou mordomia, quando a população precisa de assistência médica, alimentação, moradia, segurança, educação, isso sem falar no mínimo indispensável à existência digna. Não é preciso, para invalidar despesas desse tipo, entrar na difícil análise dos fins que inspiram a autoridade; o ato em si, o seu objetivo, o seu conteúdo, contraria a ética da instituição, afronta a norma de conduta aceita como legítima pela coletividade administrada. $\mathrm{Na}$ aferição da imoralidade administrativa, é essencial o princípio da razoabilidade (...).

O Código de Ética Profissional do Servidor Público do Poder Executivo Federal (Decreto 1.171/1994) determina que:

O servidor público não poderá jamais desprezar o elemento ético de sua conduta. Assim, não terá que decidir somente entre o legal e o ilegal, o justo e o injusto, o conveniente e o inconveniente, o oportuno e o inoportuno, mas principalmente entre o honesto e o desonesto (...). A moralidade da Administração Pública não se limita à distinção entre o bem e o mal, devendo ser acrescida da ideia de que o fim é sempre o bem comum. O equilíbrio entre a legalidade e a finalidade, na conduta do servidor público, é que poderá consolidar a moralidade do ato administrativo. 
A Afastabilidade De Ocupantes De Cargos Públicos Sem Condenação Transitada Em Julgado: Análise Da Possibilidade Em Face Da Moralidade Administrativa E Mitigação Da Presunção De Inocência Ou Violação Constitucional

De outro lado, em se tratando de direito comparado, segundo Freitas (2013, p.212) a Constituição Argentina no art. 36 consagra a ética, dizendo que: Atentará asismismo contra el sistema democrático quien incurrieren grave delito doloso contra o Estado que conlleve enriquicimiento, quedando inhabilitado por el tempo que las leyes determinen para ocupar cargos o empleos públicos, determinando que el Congreso sancionará uma ley sobre ética para el ejercicio de la funcion. A Constituição Uruguaia de 1967 não contem uma clausula genérica em matéria de ética na Administração Pública, mas há uma serie de disposições acerca da matéria:

a) $\mathrm{O}$ art. 58 afirma que los funcionários estan al servicio de la Nacion y no de una fracion politica, b) o art. 59 prescribe que el funcionário existe para la funcion y no la funcion para el funcionário, c) o art. 115 preve que cada câmara puede remover a cualquieira de sus membros por actos de conducta que hicieren indigno de su cargo, despues de su proclamacion, d) o art. 168, numeral 10, prevê como causal especifica de destituicion para los funcionários diplomáticos y consulares "la comision de actos que afecten su buen nombre o el prestigio del pais y de la representacion que invisten", e) o art. 198 faculta al Poder Ejecutivo para destituir a los miembros de los Directorios de los Entes Autonomos y de los Servicios Descentralizados, por las causales de ineptitud, omision o delito en el ejercicio del cargo o de la comision de actos que afecten su buen nombre o el prestigio de la institucion a que pertezcan, f) o art. 209 prescribe que los miembros de los Tribunales de Cuentas son responsables, ante la Asemblea General, em reunion de ambas as camaras, por el fiel y exacto cumplimiento de sus funciones.

Em 1996, a Oficina Nacional del Servicio Civil, no Uruguai, organizou Cursos de Verão para os funcionários públicos, sobre ética na função pública. Em 1999, a mesma oficina publicou um decálogo de princípios de Etica na função Publica que são: principio del serviço publico, de legalidade, de justicia e imparcialidad, de igualdad, de proporcionalidade, de colaboracion y buena fe, de información y calidad, de lealtad, de integridad, de competência e responsabilidade.

De outro prisma, o Decreto $\mathrm{n}^{\circ} 30 / 003$ do Poder Executivo Uruguaio consagra os seguintes princípios gerais de conduta na função pública: Preeminencia del interés funcional, Interés Público, Probidad, Buena Fe y Lealtad, Legalidad y obediência, Respeto, Impacialidad, Transparencia y publicidade, Eficacia y eficiência. 
Dentre os princípios supramencionados, alguns merecem destaque. Neste sentido, a preeminência del interes funcional que tem fundamento no art. 59 da Constituição Uruguaia e estabelece que o funcionário existe para a função e não a função para o funcionário. $O$ principio do interesse público se expressa na satisfação das necessidades coletivas de maneira regular e continua, na boa Fé e no exercício do poder, na imparcialidade das decisões adotadas, no desempenho das atribuições e obrigações funcionais, na retidão do seu exercício e na idônea administração dos recursos públicos. O principio da probidade, descrito no art. 11 do Decreto $n^{\circ} 30 / 003$ se traduz no fato que o funcionário público deve observar uma conduta honesta, reta e integra e descartar todo proveito ou vantagem de qualquer natureza, obtido por si ou pessoa interposta, para si ou para terceiros, no desempenho da função, com preeminência do interesse publico sobre qualquer outro.

Desta forma, conforme Freitas (2013, p. 216) os principios de ética: “imponen al funcionário público una conducta, un deber ser, que vá más allá de los preceptos jurídicos, dado que una conduta puede ser juridicamente correcta, ajustada a derecho, pero puede ser eticamente reprobable".

Diante do exposto se percebe que tanto no direito brasileiro quanto no direito alienígena se consagra e se exige os padrões éticos de probidade e boa-fé. Embora o cenário brasileiro a primeira vista não reflita verdadeiros exemplos de probidade, uma vez que, a cada dia os escândalos envolvendo políticos e ocupantes de cargos públicos aumentam vertiginosamente, enquanto muitos já denunciados e até condenados (sem o transito em julgado) ainda mantem a ocupação pública.

De outro lado, para ser mais exato, no Poder Judiciário, se observa uma face mais restritiva de interpretação da presunção de inocência. Afinal, a guisa de exemplo o Edital do XLV Concurso para Ingresso na magistratura de carreira do Estado do Rio de Janeiro, no item 04 (quatro) que menciona os requisitos para ingresso na carreira são exigidos, dentre outros, que: “i) não registrar antecedentes criminais; ii) não estar sendo processado, nem ter sofrido penalidades por prática de atos desabonadores no exercício profissional”. Deixando claro que para adentrar a carreira da magistratura o candidato não pode estar sendo processado o que confronta de forma flagrante a presunção de não culpabilidade.

Desta forma, se observa que dentro do próprio Estado Brasileiro há diferentes interpretações para a presunção de inocência. Enquanto os parlamentares processados se mantem em pleno exercício de mandado, na magistratura do Estado do Rio de Janeiro, o 
A Afastabilidade De Ocupantes De Cargos Públicos Sem Condenação Transitada Em Julgado: Análise Da Possibilidade Em Face Da Moralidade Administrativa E Mitigação Da Presunção De Inocência Ou Violação Constitucional

simples fato de sofrer um processo é um requisito suficiente para que o candidato seja excluído do certame, indicando duas medidas diferentes para o mesmo princípio.

\section{PRINCÍPIOS DE HERMENÊUTICA CONSTITUCIONAL}

Parafraseando Bulos (2010, p. 433), interpretar significa descobrir o significado, o conteúdo, e o alcance dos símbolos. Desta forma, realizar a interpretação da constituição é extrair de seus artigos, parágrafos, incisos e alíneas a sua significância e seu conteúdo intrínseco. Sob o ponto de vista cientifico, a hermenêutica ${ }^{5}$ é a ciência que estuda a interpretação, caracterizada pelo domínio teórico e especulativo que possui o objetivo de sistematizar critérios, métodos, regras, princípios científicos que busca a descoberta do conteúdo, sentido, alcance e significado das normas jurídicas.

Embora, o aforismo latino diga que in claris non fit interpretatio ${ }^{6}$, no panorama moderno nem sempre se poderá utilizá-lo na sua literalidade, uma vez que, o conteúdo meramente gramatical das normas constitucionais nem sempre consegue dirimir os problemas a que são expostos. Ademais, sem o interesse de aprofundar o tema de interpretação constitucional se faz necessário destacar a existência de uma pluralidade de métodos, princípios e técnicas ${ }^{7}$.

Dentre os princípios se pode destacar: unidade da constituição, correção funcional, concordância pratica (harmonização), eficácia integradora (ou efeito integrador), força normativa da constituição, máxima efetividade, razoabilidade (proporcionalidade), conformidade (ou justeza constitucional) que se subdivide em prevalência da constituição, conservação de normas, exclusão da interpretação contra legem.

O principio da unidade da constituição busca evitar contradições, harmonizando os espaços de tensão das normas constitucionais e assim em caso de confrontos normativos se

\footnotetext{
5 A palavra Hermenêutica advém de Hermes que na mitologia grega intermediava a comunicação entre os deuses e os homens

${ }^{6}$ Nas coisas claras não se faz interpretação

${ }^{7}$ Métodos Clássicos: gramatical, lógico, histórico, sistemático, teleológico, popular, doutrinário, evolutivo. Métodos modernos: tópico-problemático, hermenêutico-concretizador, científico espiritual, normativoestruturante da comparação constitucional. Princípios: unidade da constituição, correção funcional, concordância pratica (harmonização), eficácia integradora (ou efeito integrador), força normativa da constituição, máxima efetividade, razoabilidade (proporcionalidade), conformidade (ou justeza constitucional) que se subdivide em prevalência da constituição, conservação de normas, exclusão da interpretação contra legem. Técnicas: ponderação de valores, optimização de princípios, filtragem constitucional. In: BULOS, Uadi Lamego. Curso de Direito Constitucional. 5 ed. São Paulo: Saraiva, 2010.
} 
objetiva apaziguar os dispositivos conflitantes do sistema, privilegiando o caráter uno das constituições.

O principio da correção funcional tem por objetivo assegurar a supremacia da Constituição mediante a interpretação que preserve a constitucionalidade das normas constitucionais, representando um corolário da unidade da constituição e de extrema importância para o controle de constitucionalidade de atos normativos.

O princípio da concordância pratica busca harmonizar bens constitucionais conflitantes, a fim de evitar o sacrifício total de uns em detrimento aos outros. Por meio da concordância prática a norma interpretada à luz do fato com a qual ela interage, com o objetivo de adequar a ordem jurídica à realidade social.

O principio do efeito integrador ou eficácia integradora de acordo com Bulos (2010, p. 447) prioriza a integração politica e social do Estado, reforçando assim a sua unidade politica, pois pela sua observância a constituição não deve ser interpretada de forma parcial, mas em sua totalidade.

O princípio da força normativa da constituição determina que se houver a existência de duas ou mais interpretações possíveis será priorizada aquela que venha a conferir a maior eficácia, aplicabilidade e estabilidade as normas constitucionais. Neste aspecto, o interprete deve tornar os preceitos constitucionais efetivos e estáveis, pois tem força normativa e devem ser cumpridos e aplicados.

A máxima efetividade ou eficiência interpretativa ou ainda interpretação efetiva tem o condão de imprimir a efetividade às normas constitucionais, sacando o maior conteúdo possível, principalmente, em matéria de direitos fundamentais, fazendo prevalecer os fatos e valores consignados na Constituição.

O principio da proporcionalidade embora dispense maiores comentários traduz a ideia que a moderação sempre e imprescindível à exegese de toda e qualquer norma constitucional.

O principio da conformidade ou da interpretação conforme a Constituição determina que não se pode interpretar o texto constitucional, ferindo o sistema organizatório-funcional se irmanando com as seguintes diretrizes: prevalência da constituição, conservação das normas e exclusão da interpretação da interpretação conforme contra a legem. Para Brust (2009, p.508) na interpretação conforme a Constituição "propriamente dita" o julgador escolhe entre interpretações alternativas existentes no conteúdo normativo do preceito legal e preserva o seu texto. 
Desta forma, a prevalência da constituição indica que o interprete deve adotar a interpretação que esteja em sintonia com o texto e o contexto desta. A conservação da normas busca preservar as mesmas, uma vez que, se um diploma normativo puder ser interpretado em consonância a constituição não há porque decretar a sua inconstitucionalidade e impor o seu fim. Por derradeiro, a exclusão de interpretação conforme a constituição contra a legem significa dizer que o interprete não poder contrariar ou deturpar o significado originário das leis, ainda que tenha a intenção de adapta-las a Constituição.

Além dos princípios, o interprete ao analisar o caso concreto e interpretar a lei pode se utilizar de algumas técnicas interpretativas. De acordo com Bulos (2010, p.450) estas técnicas marcam presença na jurisprudência do Supremo Tribunal Federal e se subdividem em: técnica de ponderação de valores, técnica da optimização de princípios e técnica da filtragem constitucional.

A técnica de ponderação de princípios é um recurso utilizado pelo interprete com o objetivo de avaliar qual o bem constitucional que deve prevalecer perante a existência de conflito. Afinal, segundo Bulos (2010, p.450) os bens constitucionais integram a Constituição sem a supremacia de uns perante os outros, foram criados pelo mesmo poder constituinte e apenas pela analise do caso concreto é que se encontrará qual deverá preponderar.

Moreira (2008, p.96) diz que na busca da melhor solução em conformidade com o conteúdo Constitucional deve se realizar: “a ponderação entre o público (políticas públicas, sobretudo quando de interesse público primário) e o individual fundamental privado. $\mathrm{O}$ autor determina que essa ponderação é, essencial porque na concepção das decisões e construções jurídicas brasileiras, pois nosso regime econômico não é o liberalismo, como também não é o dirigismo social".

Ainda em se tratando de ponderação de valores, Marin (2012, p.120) diz que:

Dado o caráter principiológico das normas de Direitos Humanos e Fundamentais, e, que, nessa condição, têm a função primordial de delimitar os campos e possibilidades de interpretação e integração das demais normas constitucionais e infraconstitucionais, incumbe ao ator jurídico, ao se defrontar com um ou mais direitos fundamentais em jogo na solução de um caso concreto, fazer uma ponderação em razão do bem ou valor que se pretenda tutelar. 
Por meio da técnica de optimização de princípios o exegeta busca otimizar o conteúdo dos princípios ampliando, reduzindo, harmonizando os interesses em conflito. A técnica da filtragem da filtragem constitucional, concebida por Arturo Santoro, decorre da concepção que a ordem jurídica deve ser observada a partir da Constituição. Por exemplo, o Supremo Tribunal Federal ao filtrar os valores constitucionais assentiu que:

Os direitos e garantias individuais não têm caráter absoluto. Não há, no sistema constitucional brasileiro, direitos ou garantias que se revistam de caráter absoluto, mesmo porque razões de relevante interesse público ou exigências derivadas do princípio de convivência das liberdades legitimam, ainda que excepcionalmente, a adoção, por parte dos órgãos estatais, de medidas restritivas das prerrogativas individuais ou coletivas, desde que respeitados os termos estabelecidos pela própria Constituição. O estatuto constitucional das liberdades públicas, ao delinear o regime jurídico a que estas estão sujeitas - e considerado o substrato ético que as informa - permite que sobre elas incidam limitações de ordem jurídica, destinadas, de um lado, a proteger a integridade do interesse social e, de outro, a assegurar a coexistência harmoniosa das liberdades, pois nenhum direito ou garantia pode ser exercido em detrimento da ordem pública ou com desrespeito aos direitos e garantias de terceiros. (MS 23.425. Rel. Min. Celso de Mello, j. 16-9-1999).

\subsection{INTERPRETAÇÃO CONSTITUCIONAL E ATIVISMO JUDICIAL}

O ativismo judicial é um fenômeno que se inicia por meio da atuação da Suprema Corte dos Estados Unidos durante um período de profundas revoluções políticas naquele país. (Barroso, 2011. p.363). A partir deste momento se observa que a Corte Americana passa a adotar uma postura mais ativa, ocupando espaços omitidos pelo Poder Legislativo. De acordo com Machado (2013) "o ativismo judicial passou a se disseminar nos sistemas jurisdicionais ocidentais".

Segundo Oliveira Jr (2012, p.43), no Brasil, em decorrência da constitucionalização abrangente e analítica e do sistema de controle de constitucionalidade se observa de forma latente a judicialização da politica e das relações sociais. Para Barroso (2012) a judicialização explica que "questões relevantes do ponto de vista político, social ou moral estão sendo decididas, em caráter final, pelo Poder Judiciário”. Neste sentido, Machado (2013, p.38) diz que:

A interpretação constitucional do Supremo Tribunal Federal tem notadamente abrigado e defendido direitos e garantias fundamentais 
nas recentes decisões do tribunal. Logo, a jurisdição constitucional tem adaptado a Constituição à realidade fática de Lassale, representada pelos fatores reais de poder, reformando e atualizando conforme as situações e as pretensões dos pedidos formulados.

De forma exemplificativa Oliveira Junior (2013, p.43) destaca que o ativismo judicial passa a integrar o cotidiano do Supremo Tribunal Federal decidindo sobre os mais variados casos em que na qualidade de guardião da constituição é instado a se posicionar. Neste âmbito, são exemplos do ativismo judicial do STF as seguintes apreciações: a restrição do uso de algemas ( $\mathrm{HC} \mathrm{n}^{\circ}$ 91.952/SP e Sumula Vinculante $\mathrm{n}^{\circ} 11$ ), Aborto de fetos anencefálicos (ADPF $n^{\circ} 54$ ), pesquisas com células tronco embrionárias (ADI $n^{\circ}$ 3510/DF).

Diante do exposto, de forma resumida se observa a atuação ativista do Supremo Tribunal na guarda da constituição. Desta forma, se passa a analisar as decisões recentes do Tribunal constitucional pátrio que perpassaram por questões como: presunção de inocência, afastamento cautelar de parlamentar e critérios de inelegibilidade (Lei da Ficha Limpa), onde foram abertas divergências quanto a presunção de inocência, ao mesmo tempo em que a posição jurisprudencial do Tribunal Constitucional sofreu sensíveis mudanças interpretativas.

\section{ANÁLISE SOBRE A JURISPRUDENCIA DO SUPREMO TRIBUNAL FEDERAL}

O posicionamento do Supremo Tribunal Federal desde 2009, por meio do julgamento do HC 84078-7 MG condicionava a execução da pena ao trânsito em julgado da condenação, mas ressalvava a possibilidade de prisão preventiva. Todavia, ao negar o HC 126.292, por maioria de votos o Plenário do Supremo Tribunal Federal adotou posição contrária à jurisprudência até então mantida pelo STF.

Desta forma, vencidos a ministra Rosa Weber e os ministros Marco Aurélio, Celso de Mello e Ricardo Lewandowski cujos votos foram no sentido de manutenção da jurisprudência do Tribunal que exige o trânsito em julgado para cumprimento de pena. Neste escopo, o voto do Min. Celso de Mello destaca que:

A presunção de inocência representa uma notável conquista histórica dos cidadãos em sua permanente luta contra a opressão do Estado e o abuso de poder(...). E deferir o pedido de "habeas corpus", mantendo, em consequência, o precedente firmado no julgamento plenário do HC 84.078/MG, Rel. Min. EROS GRAU, reafirmando, assim, a tese de que a execução prematura (ou provisória) da sentença penal 
condenatória antes de consumado o seu trânsito em julgado revela-se frontalmente incompatível com o direito fundamental do réu, assegurado pela própria Constituição da República (CF, art. 5º LVII), de ser presumido inocente.

Todavia, a posição majoritária que reviu a jurisprudência do Supremo Tribunal Federal entendeu que o início da execução da pena condenatória após a confirmação da sentença em segundo grau não ofende o princípio constitucional da presunção da inocência. De acordo, com o relator Min. Teori Zavascki:

“A execução da pena na pendência de recursos de natureza extraordinária não compromete o núcleo essencial do pressuposto da não culpabilidade, na medida em que o acusado foi tratado como inocente no curso de todo o processo ordinário criminal, observados os direitos e as garantias a ele inerentes, bem como respeitadas as regras probatórias e o modelo acusatório atual. Não é incompatível com a garantia constitucional autorizar, a partir daí, ainda que cabíveis ou pendentes de julgamento de recursos extraordinários, a produção dos efeitos próprios da responsabilização criminal reconhecida pelas instâncias ordinárias".

$\mathrm{Na}$ fundamentação o Relator citou manifestação da ex-ministra Ellen Gracie, no julgamento do $\mathrm{HC} \mathrm{n}^{\circ}$ 85.886, afirmando que "em país nenhum do mundo, depois de observado o duplo grau de jurisdição, a execução de uma condenação fica suspensa aguardando referendo da Suprema Corte". Além disso, o Min. Teori afirmou que depois da entrada em vigor da Emenda Constitucional 45/2004, os recursos extraordinários só podem ser conhecidos e julgados pelo STF se, além de tratarem de matéria eminentemente constitucional, apresentarem repercussão geral, extrapolando os interesses das partes.

Portanto, mesmo que o texto constitucional expressamente fale em trânsito em julgado, percebe-se de forma clara que a decisão negatória do HC 126.292 não somente alterou a jurisprudência até então vigente no STF, como deu nova formatação à prisão, permitindo-a após a confirmação da sentença condenatória em julgamento de segunda instância, sob a alegação que esta não ofende a presunção de inocência.

Em outra decisão recente, o Supremo Tribunal Federal referendou, por unanimidade, a suspensão Eduardo Cunha (PMDB-RJ) do exercício do mandato de deputado federal e, por consequência, da função de presidente da Câmara dos Deputados por meio do julgamento da Ação Cautelar $n^{\circ}$ 4.070. O Ministro Teori Zavascki na sua fundamentação afirmou que: 
"Há indícios de que o requerido, na sua condição de parlamentar e, mais ainda, de presidente da Câmara dos Deputados, tem meios e é capaz de efetivamente obstruir a investigação, a colheita de provas, intimidar testemunhas e impedir, ainda que indiretamente, o regular trâmite da ação penal em curso no Supremo Tribunal Federal, assim como das diversas investigações existentes nos inquéritos regularmente instaurados".

A Ministra Carmen Lúcia afirmou que "A imunidade referente ao cargo não pode ser confundida com impunidade", observando que a decisão se dá de maneira excepcional e “indubitavelmente coerente com a Constituição". Trilhando pela linha da excepcionalidade da decisão o Ministro Gilmar Mendes destacou que esse tipo de solução "não pode ser matéria do cotidiano".

De acordo com o ministro Marco Aurélio, a medida acauteladora, prevista no artigo 319 do Código de Processo Penal, não é drástica, diante dos indícios e práticas implementadas por Eduardo Cunha no exercício do cargo e do mandato. Enquanto, o ministro Celso de Mello lembrou que, no sistema jurídico brasileiro, os membros dos Poderes e os agentes públicos não são imunes ao afastamento preventivo de suas funções.(grifos nossos), acrescentando que a previsão de afastamento do ocupante da Presidência da República no caso de recebimento de denúncia, estende-se aos governadores, prefeitos e magistrados, ao mesmo tempo que afirma a extraordinariedade e excepcionalidade do caso analisado.

Logo, se percebe que de forma extraordinária o Supremo Tribunal Federal reconheceu a possibilidade de afastamento preventivo tanto de membros dos Poderes, assim como de agentes públicos de suas funções, afirmando reconhecer a possibilidade mesmo que de forma excepcional.

Outra decisão importante do STF que merece destaque para a discussão proposta reside no julgamento realizado acerca da constitucionalidade da Lei Complementar $\mathrm{n}^{\circ}$ 135/2010 (Lei da Ficha Limpa) com o escopo de incluir hipóteses de inelegibilidade que visam a proteger a probidade administrativa e a moralidade no exercício do mandato. Neste aspecto, os ministros do Supremo Tribunal Federal (STF) ao realizarem a análise conjunta das Ações Declaratórias de Constitucionalidade (ADCs 29 e 30) e da Ação Direta de Inconstitucionalidade (ADI 4578) que tratam da Lei Complementar 135/2010, decidiram por maioria de votos, o entendimento em favor da constitucionalidade da lei, que poderá ser aplicada nas eleições deste ano, alcançando atos e fatos ocorridos antes de sua vigência. 
Todavia, durante o julgamento, algumas importantes fundamentações devem ser destacadas. Primeiro, o voto do Ministro Celso de Mello, ao decidir pela inconstitucionalidade da regra da Lei Complementar 135/10, que prevê a suspensão de direitos políticos sem decisão condenatória transitada em julgado. "Não admito possibilidade que decisão ainda recorrível possa gerar hipótese de inelegibilidade". A divergência aberta pelo Ministro Dias Toffoli também é importante porque baseou seu voto no princípio da presunção de inocência, salientando que só pode ser considerado inelegível o cidadão que tiver condenação transitada em julgado, enquanto a Lei da Ficha Limpa, expressamente consagra como causa de inelegibilidade a existência de sentença condenatória proferida por órgão colegiado. Sem embargo, no julgamento do HC 126.292, o Ministro Teori Zavascki, a titulo exemplificativo, lembrou que a Lei Complementar 135/2010, expressamente consagra como causa de inelegibilidade a existência de sentença condenatória proferida por órgão colegiado, afirmando que: "A presunção da inocência não impede que, mesmo antes do trânsito em julgado, o acórdão condenatório produza efeitos contra o acusado".

Diante de todo o exposto, se observa que o Supremo Tribunal Federal admitiu a hipótese de afastamento de ocupante de cargo público, ainda que, de forma excepcional. Admite que a presunção de inocência não seja óbice para imposição de certas penalidades, mesmo diante de clara divergência entre os ministros. Todavia, ainda não exista uma decisão mais ampla do STF que seja aplicada a qualquer ocupante de cargo público, sem condenação transitada em julgado, mas que permanecendo no exercício de suas atribuições poderá praticara atos lesivos a administração, aos interesses da sociedade e a moralidade administrativa.

\section{CONCLUSÃO}

Após a conflagração da operação lava jato diversos casos de corrupção tomaram conta sistemática do noticiário, envolvendo empresários, parlamentares e ocupantes de cargos públicos. Diante das delações realizadas, prisões decretadas e condenações ainda em primeira instância é assombroso o quantitativo de envolvidos. Este aspecto se tornou mais chocante para a sociedade civil quando se apresentou o quantitativo de parlamentares que devem explicações a justiça, e no exercício do mandato continuam manifestando as suas posições, recebendo recursos de natureza pública e tomando decisões políticas capaz de impactar toda a sociedade civil. 
Neste aspecto, dentre vários exemplos se destaca a participação de parlamentares inquiridos e réus que votaram no processo de impeachment quer seja para afastar ou para manter a Presidente no exercício do cargo. Independente da posição acerca da legitimidade ou não do processo de impeachment, para muitos cidadãos causou estarrecimento o fato de estes senhores, embora presumidamente inocentes e investigados pela justiça ali estivessem decidindo os rumos da sociedade brasileira, influenciando a favor ou contrariamente para a tomada de uma drástica medida na jovem democracia brasileira.

Desta forma, é cristalino que o Poder Legislativo a cada dia aumenta a perda de credibilidade perante a população. De outro giro, o Poder Judiciário aqui representado pelo Supremo Tribunal Federal, na qualidade de guardião da Constituição, passou a exercer um papel mais ativo na defesa dos direitos consagrados na Constituição. Diante desta postura de ativismo judicial o Supremo Tribunal Federal passou a buscar a efetividade dos direitos esculpidos no texto constitucional, assim como passou a se utilizar de princípios e técnicas de interpretação constitucional para atingir tal finalidade que em algumas vezes tem despertado as mais diferentes posições no meio jurídico. Além disso, também é notória a falta de celeridade processual consagrada constitucionalmente na razoável duração do processo.

Neste contexto, de maior protagonismo do Supremo Tribunal Federal e dos inúmeros casos que envolvem agente públicos, principalmente, parlamentares é que se chega ao cerne do problema enfrentado: Se estes podem ser afastados do exercício de suas funções, embora sejam presumidamente inocentes.

Diante da análise realizada se observa que a extensão da presunção de inocência muda ao longo do tempo e de acordo com a posição do STF como na divergência dos Ministros, v.g, enquanto o Ministro Dias Tofoli no julgamento das ADC's 29 e 30 e da ADIN 4578 expressou a convicção pela não admissão que decisão ainda recorrível possa gerar hipótese de inelegibilidade, com base no principio da presunção de inocência. De outro lado, o Min. Teori Zavascki no julgamento do HC 126.292 asseverou que: “A presunção da inocência não impede que, mesmo antes do trânsito em julgado, o acórdão condenatório produza efeitos contra o acusado". Portanto, se confirma no julgamento do HC 126.292 de forma excepcional que o STF passou a admitir que o acordão condenatório possa produzir efeitos contra o acusado sem violar a presunção de inocência. 
Enquanto isso a Constituição de 1988 ao destacar os princípios norteadores da Administração Pública Federal consagra dentre eles a moralidade administrativa que se explica pela exigência da adoção de condutas de probidade e boa-fé. Esta valoração e exigência jurídica de que o agente público paute sua conduta com base em critérios de probidade e boa-fé torna difícil a coexistência de um agente público na condição de réu e ao mesmo tempo probo. Neste sentido, vale repisar a observação de Freitas (2013) já expressa neste trabalho que os princípios de ética: “imponen al funcionário público una conducta, un deber ser, que vá más allá de los preceptos jurídicos, dado que una conduta puede ser juridicamente correcta, ajustada a derecho, pero puede ser eticamente reprobable”.

A esta altura se observa de forma translúcida o conflito de valores. De um lado, a presunção de inocência inserida como valor individual dentro dos direitos e garantias fundamentais, afirmando que somente se pode considerar alguém culpado após o trânsito em julgado. De outro prisma, a moralidade administrativa como principio da administração pública que exige do ocupante de cargo público o respeito aos valores éticos de probidade e boa-fé. E entre estes dois valores se observa uma miríade de inquiridos, denunciados que ainda ocupam os cargos públicos que podem se valer do exercício do cargo não somente para atrapalhar as investigações, como acarretar ainda mais prejuízos à Sociedade conforme se depreendeu no julgamento da Ação Cautelar n 4.070 .

Deste conflito, se observa que a literalidade art. $5^{\circ}$, inciso LVII, da Constituição de 1988 dentro da interpretação do Supremo Tribunal Federal ainda que com divergências de lado a lado já começa a ser aparentemente mitigado, embora a violação da sua literalidade acarrete valorosas críticas. Neste âmbito, o decano da Suprema Corte Min. Celso de Mello, no julgamento do MS n 23.425, afirmou que "Os direitos e garantias individuais não têm caráter absoluto. Não há, no sistema constitucional brasileiro, direitos ou garantias que se revistam de caráter absoluto" (...).

Devido a este cenário sui generis se faz necessário diante das circunstancias do caso concreto e por meio de adoção de métodos hermenêuticos encontrar uma solução jurídica que seja conforme a constituição de forma sistemática sem violá-la em sua essência e espirito. Outrossim, o ativismo judicial do Supremo Tribunal Federal e a mudança na jurisprudência recente em que se advogou pela mitigação da presunção de inocência em face da existência de acordão condenatório ainda não veio a apresentar uma resposta definitiva e convincente para a inquietude hermenêutica deste trabalho, além de receber numerosas críticas no meio jurídico em razão de afrontar literalmente a prescrição estabelecida pelo poder constituinte orginário. 
De outro turno, é sabido que o agente público deve manter sua ação pautada pelo respeito à moralidade administrativa que se consagra nos valores de probidade e boa-fé e recebe tratamento constitucional. Logo, é tormentoso considerar que agente público interpelado judicialmente está orientado pela probidade.

Além disso, a manutenção de réu na qualidade de agente público ainda permite que este se utilize dos recursos públicos para lograr êxito não somente para a defesa, como também para permitir a continuidade delituosa. O desrespeito sistemático a razoável duração do processo também oferece risco ao interesse público e a administração pública, uma vez que, pode manter a continuidade da prática de crimes no âmbito da administração pública, caracterizando o risco ocasionado pela demora processual.

Enquanto isso o fundamento jurídico constitucional e hermenêutico mais condizente com uma interpretação conforme a Constituição sem ferir o seu espírito pode se dar por meio da interpretação em que a presunção da inocência seja mitigada em face da moralidade administrativa, vez que, é difícil e juridicamente inaceitável que réu seja interpretado como probo, embora esta análise ainda não tenha ressonância na jurisprudência cristalizada do Supremo Tribunal Federal.

\section{REFERÊNCIAS}

ALEXANDRINO, Marcelo; PAULO, Vicente. Direito Administrativo descomplicado. 19. Ed. Rio de Janeiro: Forense; São Paulo: Método, 2011.

BARROSO, Luís Roberto. O controle de constitucionalidade no direito brasileiro: exposição sistemática da doutrina e análise crítica da jurisprudência/Luís Roberto Barroso - 5. Ed. Ver. E atual. São Paulo: Saraiva, 2011.

Luís Roberto. Constituição, democracia e supremacia judicial: direito e política no Brasil contemporâneo. 2010. In: Revista da Faculdade de Direito - UERJ. v. 2, n. 21, jan./jun. 2012 Disponível em: http://www.e-publicacoes.uerj.br/index.php/rfduerj/article/view/1794/2297. Acesso em 01 de semtembro de 2016.

BULOS, Uadi Lamego. Curso de Direito Constitucional. 5 ed. São Paulo: Saraiva, 2010.

BRUST, Leo. A Interpretação conforme a Constituição e as Sentenças Manipulativas. In: Revista Direito GV, São Paulo 5(2). p. 507-526. Jul-Dez, 2009.

DI PIETRO. Maria Zanella. Discricionariedade administrativa na Constituição de 1988, p. 111 apud CAMMAROSANO, Márcio. O princípio constitucional da moralidade e o exercício da função pública. Belo Horizonte: Fórum, 2006, p.96. 
EMPRESA BRASILEIRA DE COMUNICAÇÃO (EBC). Cerca de $60 \%$ dos deputados que julgaram Dilma têm pendências na Justiça. Disponível em: http://www.ebc.com.br/noticias/politica/2016/04/cerca-60-dos-deputados-federais-que-julgaramdilma-tem-pendencias-na Acesso em 10 de setembro de 2016.

FREITAS, Correa Ruben. Estudios de Derecho Público. Editorial Grupo Magno: Montevidéu (Uruguai), 2013.

MACHADO, Caetê Beck Guerra. INTERPRETAÇÃO CONSTITUCIONAL E ATIVISMO JUDICIAL: a sociedade aberta dos intérpretes como fundamento de legitimação nas decisões do Supremo Tribunal $\quad$ Federal. $\quad$ Disponível em http://www.repositorio.uniceub.br/bitstream/235/5140/1/RA20534162.pdf. Acesso em 30 de agosto de 2016.

MARIN, Jeferson Dytz. Hermenêutica Constitucional e Realização dos Direitos Fundamentais: o afastamento das arbitrariedades semânticas na atribuição de sentido. In: Seqüência, n. 65, p. 103-123, dez. 2012. Disponível em http://www.scielo.br/pdf/seq/n65/n65a06.pdf. Acesso em 12 de setembro de 2016.

MENDES, Gilmar Ferreira; COELHO, Inocêncio Mártires; BRANCO, Paulo Gustavo Gonet. Curso de Direito Constitucional. 5. Ed. São Paulo: Saraiva, 2010.

MOREIRA, Eduardo Ribeiro. Neoconstitucionalismo: a invasão da constituição. São Paulo: Método, 2008.

OLIVEIRA JUNIOR, Joaner Campello de. A atividade jurisdicional do Supremo Tribunal Federal a Luz da Constituição $\quad$ de $1988 . \quad$ Disponível $\quad$ em http://www.avm.edu.br/docpdf/monografias_publicadas/K222386.pdf. Acesso em 01 de setembro de 2016.

STF. Arguição de Descumprimento de Preceito Fundamenta $\mathrm{n}^{\circ}$ 144/DF. Disponível em http://www.stf.jus.br/portal/jurisprudencia/listarJurisprudencia.asp?s1=\%28144\%2ENUME\%2E+OU +144\%2EACMS\%2E\%29\&base=baseAcordaos\&url=http://tinyurl.com/z94jzfo Acesso em 19 de setembro de 2016.

STF. Habeas Corpus $\mathrm{n}^{\circ}$ 84.078/SP. Disponível em: http://www.stf.jus.br/arquivo/cms/noticiaNoticiaStf/anexo/ementa84078.pdf. Acesso em 01 de setembro de 2016.

STF. Habeas Corpus $\mathrm{n}^{\circ}$ 85.886/RJ. Disponível em: http://stf.jusbrasil.com.br/jurisprudencia/763296/habeas-corpus-hc-85886-rj Acesso em 01 de setembro de 2016.

STF. Habeas Corpus $\mathrm{n}^{\circ}$ 126.292/SP. Disponível em: http://www.stf.jus.br/portal/cms/verNoticiaDetalhe.asp?idConteudo=310153 Acesso de 01 de setembro.

STF. Habeas Corpus $\mathrm{n}^{\circ}$ 126.292. Voto Ministro Celso de Mello. Disponível em: http://www.stf.jus.br/arquivo/cms/noticiaNoticiaStf/anexo/HC126292.pdf. Acesso em 01 de setembro de 2016. 
STF. Ação cautelar $\mathrm{n}^{\circ}$ 4070. Disponível em: http://www.stf.jus.br/arquivo/cms/noticianoticiastf/anexo/ac4070.pdf Acesso em 01 de setembro de 2016.

STF. Mandado de Segurança ${ }^{\circ}$ 23.425. Rel. Min. Celso de Mello, j. 16-9-1999. Disponível emhttp://www.stf.jus.br/portal/constituicao/artigoBd.asp?item=31 Acesso em 01 de Setembro de 2016.

STF. Recurso Extraordinário $\mathrm{n}^{\circ}$ 86.297/SP. Disponível em: http://www.stf.jus.br/portal/jurisprudencia/listarJurisprudencia.asp?s1=\%2886297\%2ENUME\%2E+O $\mathrm{U}+86297 \% 2 \mathrm{EACMS} \% 2 \mathrm{E} \% 29 \&$ base=baseAcordaos\&url=http://tinyurl.com/hfz3bya. Acesso. em 19 de setembro de 2016.

TJRJ. Edital do XLV Concurso para ingresso na magistratura de carreira do Estado do Rio de Janeiro. Disponível em: http://www.tjrj.jus.br/documents/10136/1515725/edital-xlv-concurso.pdf. Acesso em 15 de setembro de 2016.

VERISSIMO, Marcos Paulo. A Constituição de 1988, vinte anos depois: Suprema Corte e ativismo judicial "à Brasileira”. In: Revista Direito GV, São Paulo 4 (2). p. 407-440. Jul-Dez, 2008. Disponível em: http://www.egov.ufsc.br/portal/sites/default/files/114.pdf. Acesso em 01 de setembro de 2016. 